\title{
PEMANFAATAN SEMAK BUNGA PUTIH (Chromolaena odorata) SEBAGAI PAKAN LOKAL SUMBER PROTEIN UNTUK TERNAK SAPI: KONSUMSI, DAYA CERNA DAN FERMENTASI RUMEN
}

\author{
Marthen L. Mullik'), I Gusti Jelantik1), Yelly M. Mulik'1), Dahlanuddin²), \\ I G. Oka Wirawan ${ }^{3)}$, Bambang Permana ${ }^{4)}$ \\ 1)Fapet Undana, Jl. Adisucipto, Kupang, NTT. \\ Email: martin_kpg@yahoo.com.au \\ ${ }^{2)}$ Fapet Universitas Mataram, Jl. Majapahit, Mataram, NTB \\ 3)Politani Negeri Kupang, Jl. Adisucipto, Kupang, NTT \\ 4)Dinas Peternakan Kab. Kupang, Jl. Timor Raya, Km 35, Oelamasi, Kupang, NTT
}

\begin{abstract}
ABSTRAK
Tumbuhan Chromolaena odorata (CO) memiliki kandungan proten tinggi (21-36\%) sehingga berpotensi sebagai sumber protein murah bagi ternak karena ketersediaannya melimpah di alam. Namun mengandung berbagai senyawa metabolik sekunder yang dapat berdampak negatif bagi ternak, sehingga perlu diolah untuk menonaktifkan antinutrisinya. Salah satu metode pengolahan adalah pembuatan pellet. Penelitian ini bertujuan untuk mendapatkan level CO yang ideal di dalam ramuan pakan komplit berbentuk pellet untuk sapi penggemukan. Empat ekor sapi bali jantan berumur \pm 2 tahun dialokasi ke dalam empat perlakuan pakan memakai rancangan bujur sangkar latin. Pelakuan terdiri dari pellet yang mengandung $10 \% \mathrm{CO}(\mathrm{COP} 10)$ atau 20\% CO (COP20), atau 30\% CO (COP30) atau 40\% CO (COP40). Pellet diberikan sebanyak 2\% dari berat badan, dan ditambah dengan jerami rumput kume ad libitum. Pakan bersifat iso-nitrogenous (20\% PK) dan iso-energi (11,5 MJ ME/kg BK). Parameter yang diukur adalah konsumsi dan daya cerna nutrisi, fermentasi rumen, dan produksi protein mikroba rumen. Hasil penelitian menunjukan bahwa level CO sebanyak 40\% secara nyata penurunan sebagian besar nilai parameter yang diukur. Konsumsi bahan kering menurun dari 2,5\% BB pada level 10\% menjadi 2,19\% pada level 40\%. Demikian juga konsumsi protein kasar yang menurun dari $749 \mathrm{~g} /$ hari (COP10) menjadi $661 \mathrm{~g} / \mathrm{hari}(\mathrm{COP} 40)$. Beberapa variabel yang tidak dipengaruhi adalah daya cerna, konsentrasi ammonia rumen (116-125 mg/dl),total VFA, dan efisiensi sintesis protein mikroba rumen (6o,4-73,4 g/kg BOT). Disimpulkan bahwa tumbuhan CO dapat digunakan sebagai pakan lokal sumber protein bagi ternak ruminansia, tetapi pada level $40 \%$ akan mulai menekan konsumsi. Sebaliknya, daya cerna dan fungsi rumen tidak dipengaruhi oleh level $\mathrm{CO}$, meskipun nilai efisiensi sintesis PMR jauh berada di bawah yang direkomendasikan dalam feeding standards. Dengan demikian, dibutuhkan proses pengolahan lain yang dapat memperbaiki nilai guna CO sebagai pakan lokal sumber protein murah bagi ternak.
\end{abstract}

Kata kunci: Chromolaeana odorata, protein murah, konsumsi, protein mikroba, sapi

\begin{abstract}
Chromolaena odorata (CO) contains high protein (21-36\%) and has the potency to be utilized as a cheap protein source for livestock due to its abundants availability. However, it also contain secondary metabolic compounds that could has a negative effects on livestock, hence it requires treatments to eliminate the antinutrient compounds. One of the methods is pelleting. This experiment aimed at assessing the efficacy of chromolaena level in pelleted ration for fattened cattle. Four bali young male aged \pm 2 years old were allotted into four dietary treatments in a latin square experimental design. The treatments were pellet contains $\mathrm{CO}$ at a level of $10 \%(\mathrm{COP} 10)$ or $20 \%(\mathrm{COP} 20)$, or $30 \%\left(\mathrm{COP}_{30}\right)$ or $40 \%(\mathrm{COP} 40)$. The pellet was offered at $2 \%$ live weight (LW), and kume grass hay was provided ad libitum as basal diet. The pellet was iso energy (11.5 MJ ME/kg DM) and nitrogenous (20\% CP). Parameters measured were dietary intake and digestibility, rumen fermentation, and rumen microbial protein production. The results showed that increasing level of chromolaena to $40 \%$ in the pellet significantly surpressed most of the measured parameters. Dry matter intake declined from 2.5\% LW in treatment COP10 to $2.19 \% \mathrm{LW}$ in COP40. Similarly, crude protein intake reduced from $749 \mathrm{~g} / \mathrm{d}(\mathrm{COP} 10)$ to $661 \mathrm{~g} / \mathrm{d}(\mathrm{COP} 40)$. Unaffected parameters were digestibility, rumen ammonia concentration (116-125 mg/dL), total VFA, and efficiency of rumen microbial protein synthesis (60,4-73,4 g/ $\mathrm{kg}$ BOT). It is concluded that chromolaena can be utilized as protein source for ruminants, yet it tends to depress intake at high level of inclusion (40\%). On the other hand, dietary digestibility and rumen function were not effected by level of chromolaean, though efficiency of rumen microbial protein synthesis was lower
\end{abstract}


than the recommended values in the exisiting feeding standards. Therefore, further research is warrant to devise appriate treatments to improve feeding value of chromolaena as cheap protein source for livestock.

Key words: Chromolaeana odorata, protein, intake, rumen microbial protein, cattle

\section{PENDAHULUAN}

Tumbuhan semak bunga putih atau ki rinyuh (Chomoralaena odorata) dewasa ini telah menginvasi dan mendominasi padang rumput alam dan lahan terbukadi wilayah lahan kering Indonesia (McFayden, 2004; Wilson dan Lane, 2006), tetapi masih dianggap sebagai gulma yang merugikan bagi pengembangan peternakan (Prawiradiputra, 2007). Ternyata, tanaman ini memiliki potensi besar untuk peningkatan produksi tanaman pangan dan ternak. Nilai positif $C$. odorata dapat dilihat dari data-data yang dilaporkan dari berbagai penelitian. Pertama, produksi biomasanya sangat tinggi yakni mencapai 70 ton bahan kering/ha/ th (Ninggeding, 2004). Kedua, tingginya kandungan nitrogen $(\mathrm{N})$ rata-rata $3,36 \%$ atau setara dengan protein kasar 21\% bahkan pada daun muda dapat mencapai 5,6\% N (Ndun, 2001; Mullik, 2002; Bamikole et al.., 2004). Ketiga, memiliki komposisi mineral (Ikhimioya et al.., 2007) dan asam-asam amino (Fasuyi et al., 2005) yang baik bagi ternak.

Pemanfaatan $C$. odorata sebagai pakan sumber protein belum lazim karena konsumsi dan palatabilitas yang tidak konsisten. Uji palatabilitas pada ternak kambing (Mullik, 2002) menunjukkan bahwa indeks kesukaan ternak terhadap C. odorata segar dan dilayukan tidak berbeda secara statistik dengan gamal dan lamtoro segar. Namun, diperlukan waktu adaptasi yang lama (1-2 bulan) sebelum ternak mulai mengkonsumsinya, karena bau yang agak menyengat berasal dari senyawa fitokimia yang dikandungnya (Ambika et al., 2004; Akinmoladun et al., 2007; Ikhimioya, et al., 2007). Selain itu, kandungan protein terlarut sangat tinggi $(58 \%)$ (Ndun, 2001) menyebabkan laju fermentasi protein dalam rumen relatif cepat sehingga terjadi akumulasi $\mathrm{NH}_{3}-\mathrm{N}$ dalam rumen dan dapat menyebabkan gangguan metabolisme. Untuk mengatasi kendala tersebut, diperlukan proses pengolahan awal, baik secara fisik/ mekanik, kimia dan/atau biologi, sehingga tumbuhan C. odorata dapat digunakan sebagai salah satu pakan lokal bernilai gizi tinggi.

Salah satu teknik pengolahan adalah melalui pembuatan pellet dimana dilibatkan proses kimia (penerapan panas pada saat penjemuran dan pembuatan pellet) dan fisik (pencincangan, penepungan, dan tekanan pada saat pembuatan pellet). Penelitian ini dirancang untuk mengevaluasi dua aspek utama yang berkaitan dengan uji $C$. odorata sebagai pakan ternak sapi penggemukan yakni level tepung $C$. odorata dalam kosentrat, dan konsentrat yang diramu dalam bentuk pellet.

\section{MATERI DAN METODE}

Penelitian ini dilakukan di kandang milik Pemerintah Kabupaten Kupang di RPH Noelbaki dan berlangsung selama 7 bulan efektif yakni dari April hingga Oktober 2013.

Empat ekor sapi bali jantan berumur 2 tahun berbobot rata-rata $195 \pm 7,11 \mathrm{~kg}$ ) dibagi ke dalam empat kelompok perlakuan berdasarkan prinsip rancangan percobaan latin square untuk menguji empat jenis ransum sebagai perlakuan yaitu:

COP10: pellet yang mengandung $10 \%$ C. odorata yang diberikan sebesar 2\% dari berat badan + hay rumput kume ad libitum

COP20: pellet yang mengandung 20\% C. odorata yang diberikan sebesar 2\% dari berat badan + hay rumput kume ad libitum

COP30: pellet yang mengandung 30\% $C$. odorata yang diberikan sebesar $2 \%$ dari berat badan + hay rumput kume ad libitum

COP4O: pellet yang mengandung 40\% C. odorata yang diberikan sebesar $2 \%$ dari berat badan + hay rumput kume ad libitum

Level $C$. odorata dalam pellet menggantikan lamtoro dalam jumlah yang sama (10-40\%). Komposisi ransum dan kandungan nutrisinya disajikan pada Tabel 1. Komposisi pellet diramu sesuai SCA (2007) untuk menyediakan tingkat pertambahan berat badan $(\mathrm{PBB})>0,6 \mathrm{~kg} / \mathrm{hari}$. Kandungan energi dan protein pellet bersifat iso untuk semua perlakuan.

Setiap periode perlakuan berlangsung selama 14 hari yang terbagi atas dua yakni 9 (sembilan) hari penyesuaian dan 5 (lima) hari koleksi data. Jumlah hari penyesuaian tidak mencapai dua minggu karena keempat jenis pakan relatif homogen dalam komposisi dan kandungan nutrisi sehingga tidak butuh waktu penyesuaian yang terlalu lama.

\section{Parameter dan cara pengukuran: \\ Konsumsi pakan.}

Konsumsi pakan diukur setiap hari selama periode pengumpulan data dengan menimbang jumlah pakan yang diberikan dan yang tidak terkonsumsi. Selisih antara yang diberikan dan yang tidak dimakan adalah total intake. Sampel pakan yang diberikan dan yang tersisa diambil setiap hari dan dikumpulkan selama masa pengumpulan data (masing-masing ternak dipisahkan). Pakan diberikan 2 kali sehari yakni pada pukul 08.00 dan pukul 16.00.

\section{Daya cerna pakan}

Pengukuran daya cerna pakan dilakukan selama 5 (lima) hari untuk setiap periode. Selama periode pengukuran daya cerna, selain dilakukan penimbangan terhadap pakan, juga dilakukan pengumpulan dan 
Tabel 1. Komposisi Nutrisi bahan Pakan Penelitian

\begin{tabular}{|c|c|c|c|c|c|c|c|c|c|}
\hline \multirow[t]{2}{*}{ Bahan Pakan } & $\begin{array}{l}\text { Bahan } \\
\text { Kering }\end{array}$ & $\begin{array}{l}\text { Bahan } \\
\text { organik }\end{array}$ & $\begin{array}{c}\text { Protein } \\
\text { kasar }\end{array}$ & $\begin{array}{c}\text { Lemak } \\
\text { kasar }\end{array}$ & $\begin{array}{c}\text { Total karbo- } \\
\text { hidrat }\end{array}$ & Serat kasar & NDF & \multirow{2}{*}{$\begin{array}{c}\text { Energy } \\
\text { metabolis } \\
(\mathrm{MJ} / \mathrm{kg} \mathrm{BK})\end{array}$} & \multirow{2}{*}{$\begin{array}{c}\text { Proporsi } \\
\text { dalam pelet }\end{array}$} \\
\hline & (g/kg) & \multicolumn{6}{|c|}{-------------------------------g/kg BK --------------------- } & & \\
\hline Hay rumput kume & 850 & 845 & 62 & 56 & 850 & 713 & 425 & 9.7 & - \\
\hline Pellet Chromolaena* & 870 & 812 & 200.6 & 63 & 604 & 551 & 380 & 11.4 & 1.00 \\
\hline Chromolaena & 831 & 890 & 210 & 61 & 619 & 682 & 421 & 10.4 & 0.10 \\
\hline Daun lamtoro & 889 & 899 & 246 & 59 & 594 & 663 & 457 & 11.7 & 0.30 \\
\hline Dedak padi & 886 & 880 & 142 & 87 & 651 & 671 & 487 & 12.2 & 0.20 \\
\hline Tepung ikan & 930 & 900 & 694 & 82 & 124 & 0 & 0 & 12.0 & 0.05 \\
\hline Urea & 950 & 0 & 2.600 & 0 & 0 & 0 & 0 & 0.0 & 0.01 \\
\hline Mineral mix & 960 & 0 & 0 & 0 & 0 & 0 & 0 & 0.0 & 0.04 \\
\hline
\end{tabular}

${ }^{*}$ )kandungan nutrisi pellet dalam tabel ini adalah untuk level C.odorata $10 \%$

penimbangan produksi feces harian. Sample feces diambil setiap hari dan dikumpulkan per periode (terpisah untuk tiap ternak) dan diambil sampel pada akhir setiap periode untuk dianalisis kandungan nutrisi sehingga koefisien kecernaan dapat dihitung.

\section{Konsentrasi VFA dan amonia rumen.}

Cairan rumen diambil dua kali pada hari terakhir pengukuran daya cerna. Cairan pertama diambil pada o jam sebelum diberi pakan, sedangkan cairan kedua diambil pada 3-4 jam setelah diberi pakan. Pengambilan cairan rumen dilakukan menggunakan selang yang dimasukkan ke dalam rumen melalui mulut dan dihubungkan dengan pompa vakum. Sekitar $250 \mathrm{ml}$ cairan rumen disedot, disaring pakai 4 lapis socking. Sekitar $100 \mathrm{ml}$ dipindahkan ke kontainer plastik, diberi beberapa tetes asam sulfat pekat untuk menurunkan $\mathrm{pH}$ dibawah 3. Selanjutnya sekitar 100 ml dipindahkan ke dalam 2 kontainer plastik (masingmasing $50 \mathrm{ml}$ ) ditutup dan disimpin dalam freezer sambil menunggu untuk dianalisis VFA dan amonia.

Produksi, efisiensi dan pasokan protein mikroba rumen

Pengukuran produksi dan efisiensi sintesis protein mikroba rumen (PMR) akan menggunakan indikator konsentrasi turunan purin (allantoin, asam urat, xanthine, dan hypoxanthine) dalam urin. Produksi urin harian ditampung selama pengukuran daya cerna. $\mathrm{pH}$ urin dipertahankan di bawah 3 dengan cara menambahkan sekitar $100 \mathrm{ml} 10 \% \mathrm{H}_{2} \mathrm{SO}_{4}$ dalam wadah penampungan sesaat sebelum urin ditampung. Setiap hari, urin ditimbang, diambil $5 \%$ dan dimasukkan ke dalam jerigen dan disimpan di refrigerator (masingmasing ternak terpisah). Pada akhir setiap periode, diambil sampel dari masing-masing jerigen sebesar 5 ml dan dipindahkan ke dalam tube plastik bertutup yang telah dimasukkan $1 \mathrm{ml}$ allopurinol (internal standard). Selanjutnya ditambahkan larutan buffer $\left(\mathrm{o}, 1 \mathrm{M} \mathrm{NH} \mathrm{H}_{2} \mathrm{HO}_{4}\right)$ sebanyak $44 \mathrm{ml}$ sehingga total larutan menjadi $50 \mathrm{ml}$. Tube plastik tersebut diberi label dan disimpan dalam freezer menunggu dianalisis kandungan purinnya. Perhitungan produksi dan efisiensi sintesis PMR menggunakan rekomendasi untuk sapi Bos indicus yakni $\mathrm{Y}=0,85 \mathrm{X}+0.147 \mathrm{~W}^{0.75}$ (IAEA, 2003).

\section{Profil metabolit plasma darah (urea dan glukosa)}

Sampel darah diambil menggunakan syringe pada hari terakhir setiap periode pengukuran daya cerna. Darah ditampung dalam vaccutainer berheparin dan selanjutnya disentrifuge pada kecepatan $200 \mathrm{rpm}$. Plasma dipisahkan dan disimpan dalam vial $5 \mathrm{ml}$ dalam freezer, menunggu untuk dianalisa lab.

\section{Analisis data}

Data yang diperoleh dianalisis sesuai prosedur general lenear model (GLM) untuk data univariate menggunakan prinsiprRancangan bujur sangkar latin. Perlakuan dinyatakan berbeda nyata pada nilai $\mathrm{P} \leq 0,05$.

\section{HASIL DAN PEMBAHASAN}

\section{Konsumsi dan daya cerna}

Data konsumsi dan daya cerna menunjukkan bahwa peningkatan level $C$. odorata dalam pellet dari $10 \%$ hingga $40 \%$ sangat nyata menurunkan semua variabel konsumsi, tetapi tidak mempengaruhi tingkat daya cerna. Total konsumsi bahan kering terendah dicapai perlakuan COP4O yakni $2,19 \%$ berat badan (BB) ternak, sedangkan tertinggi pada COP2O $(2,57 \%$ BB). Data ini menggambarkan bahwa penurunan konsumsi pada level $C$. odorata $40 \%$ tidak disebabkan oleh kandungan ntrisi pakan karena semua perlakuan memiliki kandungan protein dan energi yang sama. Penurunan ini cenderung diperkirakan berkaitan dengan meningkatnya intake senyawa metabolik sekunder seiring meningkatnya proporsi tepung C. odorata dalam ransum. Trend yang sama juga dilaporkan pada ternak domba dan kelinci (Apori et al., 2001; Bamikole et al., 2004; Aro et al, 2009) ketika level $C$. odorata mencapai $40 \%$ dari total ransum. Secara empiris, data pada Tabel 2 memperlihatkkan bahwa terjadi peningkatan konsumsi ketika level C. odorata mencapai 20\%. Penelitian pada ternak domba di Ghana (Yakuba, 2012) juga memperlihatkan peningkatan konsumsi dan daya cerna ketika level inclusi $C$. odorata meningkat ke $20 \%$.

Konsumsi nutrisi lainnya (BO, PK, LK) juga ikut menurun mengikuti trend konsumsi BK. Hal ini logis karena kepadatan nutrisi semua ransum sama 
Tabel 2. Rata-rata konsumsi dan daya cerna pakan berbentuk pellet yang mengandung Chromolaena odorata sebanyak 10\% (COP10) atau 20\% (COP20) atau 30\% (COP30) atau 40\% (COP40) oleh ternak sapi bali penggemukan yang diberikan sebesar 2\% dari bobot badan (BB)

\begin{tabular}{|c|c|c|c|c|c|c|}
\hline Parameter & COP10 & COP20 & COP30 & COP40 & SEM & Nilai $P$ \\
\hline \multicolumn{7}{|l|}{ Konsumsi total: } \\
\hline Bahan kering $\left(\mathrm{kg}^{-\mathrm{h}}\right)$ & $4,86^{a}$ & $5,02^{a}$ & $4,78^{a}$ & $4,28^{b}$ & 0,007 & 0,002 \\
\hline Bahan kering (\%BB) & $2,51^{a}$ & $2,57^{a}$ & $2,46^{a}$ & $2,19^{b}$ & 0,010 & 0,001 \\
\hline Bahan organik $\left(\mathrm{kg}^{-\mathrm{h}}\right)$ & $4,00^{\mathrm{a}}$ & $4,14^{\mathrm{a}}$ & $3,93^{\mathrm{a}}$ & $3,52^{b}$ & 0,061 & 0,015 \\
\hline Protein kasar $\left(\mathrm{g}^{-\mathrm{h}}\right)$ & $749^{a}$ & $771^{a}$ & $730^{a}$ & $661^{b}$ & 13,134 & 0,005 \\
\hline Protein lemak kasar $\left(\mathrm{g}^{-\mathrm{h}}\right)$ & $295 a$ & $305 a$ & $290 a$ & $260 b$ & 4,416 & 0,002 \\
\hline Bahan organik tercerna $\left(\mathrm{g}^{-\mathrm{h}}\right)$ & $2,75^{a}$ & $2,81^{a}$ & $2,60^{\mathrm{a}}$ & $2,32^{\mathrm{b}}$ & 0,074 & 0,013 \\
\hline Rasio protein:BOT & 273 & 275 & 281 & 288 & 8,962 & 0,582 \\
\hline \multicolumn{7}{|l|}{ Daya Cerna: } \\
\hline Bahan kering (\%) & 63 & 62 & 60 & 59 & 1,435 & 0,362 \\
\hline Bahan orgnaik(\%) & 68 & 67 & 66 & 65 & 1,212 & 0,341 \\
\hline Protein kasar (\%) & 83 & 83 & 82 & 82 & 0,640 & 0,317 \\
\hline Retensi nitrogen $\left(\mathrm{g}^{-\mathrm{h}}\right)$ & $100^{a}$ & $103^{a}$ & $96^{\mathrm{a}}$ & $87^{b}$ & 2,121 & 0,008 \\
\hline
\end{tabular}

sehingga tingkat konsumsi BK menjadi penentu tingkat konsumsi nutrisi lainnya. Penurunan konsumsi mengindikasikan bahwa meskipun $C$. odorata telah dibuat dalam bentuk tepung serta diproses menjadi pellet, kandungan alkaloidnya masih belum hilang total sehingga masih berpengaruh negatif. Pengaruh negatif dari penggunaan tepung daun $C$. odorata dalam ransum juga didapati oleh Yakubu (2012) pada profil hormon reproduksi dan kesehatan testes serta sperma tikus percobaan.

Tidak seperti konsumsi, parameter daya cerna (Tabel 2) tidak dipengaruhi secara nyata oleh peningkatan level $C$. odorata dalam pellet. Kisaran daya cerna BK ransum adalah 59-63\%, sedangkan daya cerna BO lebih tinggi 5-6\% dari daya cerna BK. Daya cerna BK yang yang diperlihatkan dalam penelitian ini relatif rendah mengingat kandungan konsentrat memilik PK cukup tinggi (20\%) dan ME yang padat (11,4 MJ ME/ $\mathrm{kg}$ BK) serta diberikan sebanyak $2 \%$ dari bobot badan. Namun, hal ini dapat dijelaskan dari bentuk fisik pakan yang telah diolah dalam bentuk tepung dan dipellet sehingga proporsi pakan lolos fementasi rumen (bypass) relatif tinggi seperti umumnya dilaporkan untuk pakan olahan (Klopfenstein, 1996).

Rasio konsumsi protein kasar (PK), konsumsi bahan organik tercerna (BOT) menggambarkan jumlah dan keseimbangan protein dan energi yang dikonsumsi ternak. Pada Tabel 2 terlihat bahwa rasio konsumsi PK:BOT berkisar antara 273-288 g PK/kg BOT. Angka ini jauh berada di atas standar minimal (170 $\mathrm{g}$ protein terlarut dalam rumen per $\mathrm{kg}$ BOT) yang disarankan untuk produksi protein mirkoba optimum (SCA, 2007; NRC, 2000; Van Soest, 1996). Rasio yang sedemikian baik dalam ransum yang dikonsumsi pada penelitian ini memang ditujukan untuk memberikan pertambahan bobot badan harian $>0,6 \mathrm{~kg}$.

Nilai retensi nitrogen dapat digunakan sebagai indikator kasar memprediksi kemungkinan tingkat PBB yang dapat dicapai oleh ternak. Retensi N nyata terrendah pada COP4O (87 g N/hari) dibanding dengan ketiga perlakuan lainnya (96-103 g N/hari). Apabila kita menggunakan asumsi (NRC, 2000; SCA, 2007) bahwa semua PK yang diretensi dalam tubuh ternak sapi penelitian menempati 20\% dari setiap bobot ternak kosong, maka secara kasar dapat diduga bahwa laju PBB harian ternak penelitian akan berkisar antara 435-515 kg/hari.Laju PBB prediktif menggambarkan bahwa pakan diramu dalam penelitian ini memang dapat mendukung laju PBB $>0,6 \mathrm{~kg} /$ hari. Memang laju PBB yang dicapai oleh ternak penelitian masih di bawa $0,6 \mathrm{~kg} /$ hari karena konsumsi BK hanya berkisar 2,19-2,57\% BB di mana masih di bawah level ideal yakni 3\% BB.

Rendahnya retensi $\mathrm{N}$ pada perlakuan $\mathrm{COP} 40$ karena total konsumsi PK termak secara nyata paling rendah dibanding dengan ketiga perlakuan lainnya. Pada sisi lain, daya cerna antar semua perlakuan tidak nyata berbeda. Dengan demikian, rentensi sangat ditentukan oleh tingkat konsumsi PK, bukan oleh daya cerna.

\section{Fermentasi rumen dan plasma metabolit}

Data fermentasi rumen yang diperoleh pada penelitian ini tidak menunjukkan adanya perbedaan secara statistik akibat peningkatan level $C$. odorata (Tabel 3). Hal ini menggambarkan bahwa tidak ada perbedaan dalam pemanfaatan C. odorata dan lamtoro oleh ternak. Level $C$. odorata tidak berpengaruh karena peningkatan level $C$. odorata diikuti dengan penurunan level lamtoro yang sama besarnya dalam ransum (substitusi) sehingga kepadatan nutrisi ransum tidak berubah. Ada dua faktor yang mempengaruhi. Pertama, kandungan nutrisi $C$. odorata dan lamtoro tidak jauh berbedan (Tabel 1). Kedua, pemberian urea sebagai buffer untuk menjaga kompoisi pakan tetap iso-nitrogenous.

Tabel 3. Fermentasi rumen dan metabolit plasma darah pada ternak sapi bali jantan yang diberikan pellet dengan kandungan Chromolaena odorata sebesar $10 \%$ (COP10) atau $20 \%$ (COP20) atau $30 \%$ (COP30) atau $40 \%$ (COP40) sebanyak $2 \%$ dari bobot badan

\begin{tabular}{lrrrrrr}
\hline \multicolumn{1}{c}{ Parameter } & COP10 & COP20 & COP30 & COP40 & SEM & Nilai P \\
\hline pH cairan rumen & 6,90 & 6,70 & 6,73 & 6,71 & 0,342 & 0,542 \\
$\mathrm{NH}_{3}$-N Rumen (mg/l) & 116 & 125 & 109 & 119 & 12,1 & 0,808 \\
Total VFA (mM) & 128,4 & 132,3 & 134,7 & 130,1 & 2,58 & 0,725 \\
$\quad$ Acetat (mM) & 88,4 & 86,3 & 88,3 & 85,5 & 4,631 & 0,961 \\
$\quad$ Butirat (mM) & 12,3 & 12,9 & 16,4 & 10,6 & 1,98 & 0,564 \\
$\quad$ Propionat (mM) & 27,6 & 30,5 & 30,1 & 34,5 & 2,78 & 0,562 \\
Rasio C 2 equivalen : & 3,67 & 3,50 & 3,64 & 3,85 & 0,061 & 0,714 \\
propionat & & & & & &
\end{tabular}

propionat 
Tabel 4. Konsentrasi turunan purin, produksi dan efisiensi sintesis protein mikroba rumen (PMR) pada ternak sapi bali yang diberikan pakan komplit berbentuk pellet yang mengandung Chromolaena odorata sebanyak 10\% (COP10) atau 20\% (COP20) atau 30\% (COP30) atau 40\% (COP40) yang diberikan sebesar $2 \%$ dari bobot badan (BB)

\begin{tabular}{|c|c|c|c|c|c|c|}
\hline Parameter & COP10 & COP20 & COP30 & COP40 & SEM & Nilai P \\
\hline \multicolumn{7}{|l|}{ Ekskresi turunan purin: } \\
\hline Kreatinin (mmol/h) & 33,3 & 29,7 & 26,0 & 20,4 & 4,57 & 0,316 \\
\hline Kreatinin $\left(\mathrm{mmol} / \mathrm{kg} \mathrm{BB}^{0,75}\right)$ & 0,63 & 0,57 & 0,50 & 0,39 & 0,264 & 0,301 \\
\hline Total derivate purin (DP; $\mathrm{mmol} / \mathrm{h}$ ) & 46,2 & 43,7 & 42,5 & 33,1 & 5,56 & 0,433 \\
\hline Allantoin (mmol/h) & 41,3 & 38,2 & 39,1 & 29,9 & 5,148 & 0,481 \\
\hline Uric acid (mmol/h) & 4,89 & 5,45 & 3,44 & 3,18 & 0,702 & 0,157 \\
\hline Molar rasio PD : kreatinin & 1,38 & 1,55 & 1,63 & 1,63 & 0,264 & 0,235 \\
\hline Molar rasio allantoin : kreatinin & 1,48 & 1,22 & 1,35 & 1,49 & 0,107 & 0,372 \\
\hline PD yang diabsorbsi (mmol/h) & 45,4 & 42,3 & 41,0 & 30,0 & 6,500 & 0,429 \\
\hline \multicolumn{7}{|l|}{ Estimasi produksi PMR: } \\
\hline g PMR/h & 206 & 192 & 186 & 136 & 29,970 & 0,428 \\
\hline $\mathrm{g}$ PMR $/ \mathrm{kg} \mathrm{BB}^{0,75}$ & 3,92 & 3,68 & 3,57 & 2,60 & 0,545 & 0,407 \\
\hline g PMR /kg BOT* & 73,4 & 68,3 & 71,7 & 60,4 & 0,801 & 0,801 \\
\hline
\end{tabular}

*BOT= bahan organik tercerna

Total konsentrasi VFA dalam cairan rumen yang diperoleh dalam penelitian ini juga tidak menunjukkan adanya pengaruh level $C$. odorata (Tabel 2) karena komposisi ransum yang sama kandungan nutrisinya seperti yang sudah dijelaskan di depan. Rentangan nilai VFA yang diperoleh dalam penelitian ini mirip dengan yang dilaporkan oleh Hidayat (2012) pada ternak sapi bali penggemukan yang diberikan konsentrat yang sama kandungan nutrisinya dengan pellet yang digunakan dalam penelitian ini, dan diberikan pada level yang juga sama yakni 2\% BB. Aspek yang berbeda dari penelitian Hidayat (2012) adalah pakan basalnya berupa silage jagung.

\section{Produksi dan efesiensi sintesis protein mikroba rumen}

Total produksi dan efisiensi sintesis protein mikroba rumen (PMR) tidak nyata dipengaruhi oleh level tepung C. odorata dalam pellet (Tabel 4).

Tingkat efisiensi sintesis PMR yang hanya berkisar 60,4-73,4. Nilai ini berada jauh di bawah standar minimal yang direkomendasikan dalam feeding standar (SCA, 2007; NRC, 2000). Efisiensi PMR yang rendah inilah yang mengakibatkan total produksi PMR juga rendah (192-206 g PMR/h). Tidak berbedanya produksi serta rendahnya tingkat efisiensi sintesis PMR mungkin berkaitan dengan bentuk fisik pakan (pellet) yang lebih banyak lolos tanpa terfermentasi penuh di rumen. Akibatnya, tidak tersedia banyak nutrisi bagi mikroba untuk berkembangbiak. Jumlah sel mikroba yang terbentuklah yang menentukan total pasokan protein asal miroba yang tiba di usus halus untuk diserap bagi kepentingan jaringan.

Dari pasokan PMR yang diperoleh dalam penelitian ini, dapat dikalkulasi jumlah net protein yang tersedia untuk deposisi protein tubuh ternak. Dengan mengacu pada persamaan-persamaan yang digunakan dalam Feeding Standard terkini (SCA, 2007; NRC, 2000) dimana diasumsikan bahwa sel mikroba mengandung $20 \%$ asam nukleat, daya cerna proteinnya di usus halus sebesar $65 \%$, maka total protein metabolis (MP) yang tersedia dari mikroba rumen untuk ternak inang berkisar 31,8-38,2 g MP/hari. Apabila efisiensi penggunaan MP diasumsikan 30\%, maka jumlah net protein (NP) yang tersedia untuk PBB sebesar 9,4-11,5 g NP/hari atau setara dengan PBB 47,1$57,3 \mathrm{~g} /$ hari. Berdasarkan hasil kalkulasi inilah maka kita dapat menduga bahwa protein yang diretensi dalam tubuh ternak seperti yang ditunjukkan dalam Tabel 2 sebagian besar berasal dari protein pakan yang lolos dari fermentasi rumen. Dengan demikian dapat diyakini bahwa pemberian pakan berbentuk pellet tidak maksimumkan fungsi rumen tetapi lebih menyediakan nutrisi yang lolos dari fermentasi rumen untuk digunakan oleh ternak.

\section{SIMPULAN}

Berdasarkan hasil penelitian ini dapat disimpulkan, C. odorata memiliki potensi besar untuk digunakan sebagai bahan pakan lokal sumber protein, tetapi pemberian hinggal level 40\% dalam pakan komplit berbentuk pellet sangat nyata menurunkan semua parameter intake, meskipun semua parameter daya cerna tidak dipengaruhi. Selain itu, pakan dalam bentuk pellet tidak memaksimumkan fungsi rumen tetapi lebih bersifat by-pass sehingga efisiensi sintesis protein mikroba rumen hanya berkisar 60-70 g PMR/ kg BOT. Pengaruh negatif dari $C$. odorata diduga kuat berkaitan dengan senyawa metabolik sekunder yang dikandungnya sehingga dibutuhkan penelitian tentang perlakuan-perlakuan pengolahan untuk mengatasi masalah negatif tersebut.

\section{DAFTAR PUSTAKA}

Apori, S.O., Odoi, F.N.A., dan Ganto, E. 2001. Intake and digestibility of organic matter and nitrogen in Chromolaena odorata leaf meal-based diets by sheep. Ghana J, Agric. Sci., 34:11-14.

Aro, S.O., Osho, I.B., Aletor, V.A. dan Tewe, O.O. 2009. Chromolaena odorata in livestock nutrition.J. Med. Plant Res., 3(13)1253-1257.

Bamikole, M.A., Ikhatua, U.J. and Osemwenkhae, A.E. 2004. Converting Bush to Meat: A Case of Chromolaena 
odorata Feeding to Rabbits. Pakistan Journal of Nutrition $3(4): 258-261$,

Fasuyi, A. O., Fajemilehin, K. S.O. dan Oro, S.O. 2005. Nutritional Potentials of Siam Weed (Chromolaena odorata) Leaf Meal on Laying Hens: Biochemical and Haematological Implications. Pakistan Journal of Nutrition 4 (5): 336-341.

Hidayat, M. 2012. Pengaruh Kualitas Pakan dan Latar Belakang Nutrisi Yang Berbeda Terhadap Pemanfaatan Nutrisi dan Petrformans Sapi Bali Selama Periode penggemukan. Thesis. Program Pascasarjana, Undana.

Ikhimioya, I., Bamikole, M. A. and Omoregie, A. U., Ikhatua, U. J. 2007. Compositional evaluation of some dry season shrub and tree foliages in a transitionally vegetated zone of Nigeria.Livestock Research for Rural Development 19 (3): $1-9$

Klopfenstein, T. 1996. Need for escape protein by grazing cattle. Anim. Feed Sci. Technol., 60:191-199.

Leng, R.A., and Nolan, J.V. 1984. Nitrogen metabolism in the rumen.J. Dairy Sci., 67:1072-1089.

McFadyen, R.C. 2004. Chromolaena in East Timor: history, extent and control. In Chromolaena in he Asia-Pacific Region.Editors:M.D. Day and R.E. McFadyen. ACIAR Technical Reports No. 55,pp. 8-10.

Mullik, M. L. 2002. Laporan Penelitian: Strategi Pemanfaatan Semak Bunga Putih (Chromolaena odorata) Untuk Meningkatkan Produksi Ternak Dan Pendapatan Peternak di
Di Daerah Lahan Kering. Kerjasama Fakultas Peternakan Universitas Nusa Cendana dengan Kementrian Riset dan Teknologi Republik Indonesia melalui Riset Pengembangan Kapasitas.

National Research Council (NRC). 2000. Nutrient Requirement of Beef Cattle. $8^{\text {th }}$ Edition. National Academy Press

Ndun, M. L. 2001. Degradabilitas Bahan Kering, Bahan Organik, dan Protein Kasar Chromolaena odorata. Skripsi. Fakultas Peternakan Universitas Nusa Cendana.

Ninggeding, D. 2004. Produksi Biomasa Chromolaena odorata pada interval pemangkasan yang berbeda.Skripsi.Fakultas Peternakan Universitas Nusa Cendana.

Prawiradiputra, 2007.Ki Rinyuh (Chromolaena odorata; R.M. King dan H. Robinson): Gulma Padang Rumput yang Merugikan. WARTAZOA 17(1): 12-18.

SCA. 2007. Feeding Standards For Australian Livestock. Standing Committee on Ruminants, CSIRO.

Van Soest, P.J. 1996. Nutritional Ecology of the Ruminant.2nd Ed. Cornell University Press.

Wilson, C. dan Lane, A. 2006. Chromolaena odorata. Parks \& Wildlife Commission of the Northern Territory \& Invasive Species Specialist Group (ISSG) News Letter.

Yakuba, M.T. 2012. Effect of a 60-day oral gavage of a crude alkaloid extract from Chromolaena odorata leaves on hormonal and spermatogenic indices of male rats. $J$. Adrology, 33(6):1199-1207. 